\title{
Galectin-3 Determines Tumor Cell Adaptive Strategies in Stressed Tumor Microenvironments
}

\author{
Ana Carolina Ferreira Cardoso, Luciana Nogueira de Sousa Andrade, Silvina Odete Bustos \\ and Roger Chammas*
}

Departamento de Radiologia e Oncologia, Faculdade de Medicina, Centro de Investigação Translacional em Oncologia, Instituto do Câncer do Estado de São Paulo, Universidade de São Paulo, São Paulo, Brasil

Galectin-3 is a member of the $\beta$-galactoside-binding lectin family, whose expression is often dysregulated in cancers. While galectin-3 is usually an intracellular protein found in the nucleus and in the cytoplasm, under certain conditions, galectin-3 can be secreted by an yet unknown mechanism. Under stressing conditions (e.g., hypoxia and nutrient deprivation) galectin-3 is upregulated, through the activity of transcription factors, such

OPEN ACCESS

Edited by:

Lucia Mendonça-Previato, Universidade Federal do Rio de

Janeiro, Brazil

Reviewed by:

Franklin David Rumjanek, Universidade Federal do Rio de Janeiro, Brazil

Anthony Peter Corfield, University of Bristol, UK Diego Croci,

Instituto de Histología y Embriología de Mendoza-CONICET, Argentina

*Correspondence: Roger Chammas rchammas@usp.br

Specialty section: This article was submitted to Molecular and Cellular Oncology, a section of the journal Frontiers in Oncology

Received: 25 February 2016 Accepted: 10 May 2016

Published: 23 May 2016

Citation:

Cardoso ACF, Andrade LNS, Bustos SO and Chammas R (2016)

Galectin-3 Determines Tumor Cell Adaptive Strategies in Stressed Tumor Microenvironments.

Front. Oncol. 6:127. doi: 10.3389/fonc.2016.00127 as HIF- $1 \alpha$ and NF-kB. Here, we review evidence that indicates a positive role for galectin-3 in MAPK family signal transduction, leading to cell proliferation and cell survival. Galectin-3 serves as a scaffold protein, which favors the spatial organization of signaling proteins as K-RAS. Upon secretion, extracellular galectin-3 interacts with a variety of cell surface glycoproteins, such as growth factor receptors, integrins, cadherins, and members of the Notch family, among other glycoproteins, besides different extracellular matrix molecules. Through its ability to oligomerize, galectin-3 forms lectin lattices that act as scaffolds that sustain the spatial organization of signaling receptors on the cell surface, dictating its maintenance on the plasma membrane or their endocytosis. Galectin-3 induces tumor cell, endothelial cell, and leukocyte migration, favoring either the exit of tumor cells from a stressed microenvironment or the entry of endothelial cells and leukocytes, such as monocytes/macrophages into the tumor organoid. Therefore, galectin-3 plays homeostatic roles in tumors, as (i) it favors tumor cell adaptation for survival in stressed conditions; (ii) upon secretion, galectin-3 induces tumor cell detachment and migration; and (iii) it attracts monocyte/macrophage and endothelial cells to the tumor mass, inducing both directly and indirectly the process of angiogenesis. The two latter activities are potentially targetable, and specific interventions may be designed to counteract the protumoral role of extracellular galectin-3.

Keywords: galectin-3, cell signaling, migration, angiogenesis, tumor microenvironment

\section{GALECTIN-3 AND ITS KEY STRUCTURE TO FUNCTION RELATIONSHIPS}

Besides the common sense that most of the biological information resides in both nucleic acid and amino acid sequences, glycans present either on the cell surface or in the extracellular matrix (ECM) molecules also constitute an important reservoir of biological information. The coding capacity of carbohydrates is much broader than DNA sequences and peptides due to the structural 
and conformational diversity displayed by these molecules (1). This so-called "sugar code" collectively defines boundaries within tissues, thus serving as a constitutive territorial marker, besides indicating transient states of the cells present within these tissues. Different animal lectins, glycan-binding proteins, decipher the biological information imprinted in the "sugar code" and trigger signaling pathways, orchestrating a variety of biological and pathophysiological processes.

Animal lectins are categorized into structurally related families and superfamilies, based on highly conserved carbohydrate recognition domains (CRDs) (2). Within the lectin superfamilies, galectins constitute a family of animal lectins known to mediate a plethora of processes like cell adhesion, migration, survival, death, and differentiation. Initially termed S-type lectins, galectins are a group of proteins expressed in all organisms. Galectins are characterized to bind $\beta$-galactose-containing glycoconjugates and share primary structural homology in their CRDs (3). This family, composed by 15 mammalian galectins, is classified in three subtypes or groups, namely (i) prototype, (ii) chimera, and (iii) tandem repeat group, according to the number and organization of CRDs (4).

Galectin-3 is the only member of the chimera group (5). Galectin-3, initially known as Mac-2, €BP, CBP35, CB-30, and L29 among another names, is one of the best studied lectins and is constituted by three distinct domains: an $\mathrm{NH} 2$-terminal domain, a proline-rich collagen- $\alpha$-like domain, and a $\mathrm{COOH}$-terminal domain that contains the CRD (6). This protein is encoded by a single gene in humans (LGALS3) composed of five introns and six exons located in chromosome 14, locus q21-q22, and the protein has a molecular weight of $\sim 31 \mathrm{kDa}(7,8)$. Its promoter region, as well as its first exon, exhibits a high content of CpG islands, indicating that epigenetic mechanisms also control galectin-3 expression, as observed during malignant transformation and tumor progression (9).

Members of the galectin family bind simple $\beta$-galactosides, such as disaccharides or trisaccharides. However, this affinity is relatively weak compared to binding to natural glycoconjugate ligands expressed on cell surfaces or in the ECM. Galectin CRDs recognize different types of glycan ligands and show high affinity binding to different structures. Galectin-3 was originally described to bind preferentially to type 1 or type $2 \mathrm{Gal} \beta 1 \rightarrow 3(4)$ $\operatorname{GlcNAc}(N$-acetyllactosamine) chains, and its affinity increases for polylactosamine structures and/or branched glycans over simple saccharides (10) (For more information, access "Consortium for Functional Glycomics," Paradigm pages, accessed February 22, 2016, http://www.functionalglycomics.org). However, specific binding of galectin-3 may be attenuated or enhanced, depending on the substituents that modify subterminal galactose residues in the galectin ligand. Accordingly, galectin-3 shows higher affinity to oligosaccharides bearing 2- or 3-O- $\alpha$-substituents on the outer galactose residue of glycans, such as NeuNAc $\alpha 2,3$ lactosamine or the A-blood group structure GalNAc $\alpha 1,3$ [Fuc $\alpha 1,2]$ Gal $\beta 1,4$ GlcNAc (11). Additionally, sialylation and sulfation of glycoconjugates also interfere on the carbohydrate affinity and the specificity of galectins. For example, presence of $3^{\prime}$-O-sulfated or $3^{\prime}-O$-sialylated glycoconjugates increases the affinity toward galectin-8 (12). Otherwise, 6-O- $\alpha$-substitution by sialic acid reduces galectin-3 carbohydrate affinity (13-16). Suzuki and colleagues have also demonstrated that pretreatment of H-ALCL cells with neuraminidase, which cleaves cell surface sialic acid, increases galectin-3 adhesion to integrins (17).

Carbohydrate-binding characteristics of galectins involve (i) the array of glycan ligands; (ii) the architecture, dynamics, and binding sites of CRDs; and (iii) the topological display of glycans. It has been suggested that differences in the amino acid properties of galectins are responsible for the different binding of glycans to the CRDs, since the 3D structure of the galectin CRDs have an almost identical fold, while their amino acid sequence identity is rather low (18-20). For example, the CRD of galectin-3 is $30-40 \%$ identical with galectins $4-10$ and $20-25 \%$ identical with galectin-1 and -2 (21-23). These differences provide specific structural features that determine carbohydrate-binding specificity. For example, galectin-3 has a higher affinity for GalNAc than galectin-1, due to an arginine residue at position 144 (23). The topological display of glycan ligands in glycoconjugates (glycoclusters) is also important to an appropriate spatial match between lectin domains and polyvalent ligands (24, 25). Upon binding, galectins may form supramolecular structures due to the formation of homodimers and multimers. Altogether, the binding characteristics of each galectin and their ability to form higher order complexes with their ligands will determine the biological functions ascribed to galectins.

The relationship between the quaternary structure and galectin-3 precipitation activity also provides information about its structure-bioactivity and binding properties. There are two mechanisms for the formation of oligomers of galectin-3; an $\mathrm{N}$-terminal-dependent and a C-terminal-dependent association (26). The N-terminal-dependent association of galectin-3 was the first oligomerization mechanism described (27-30). In solution, monomeric galectin-3 is in equilibrium with oligomers and may precipitate as a pentamer in the presence of multivalent oligosaccharides (31-35). The N-terminal domains confer oligomer flexibility, making the overall oligomer highly flexible, which contribute to galectin-3 ability to dynamically convert to pentamers that form heterogeneous cross-linked complexes with specific multivalent glycoconjugates (33). The capacity of forming multivalent oligomers is responsible for the formation of lattices on plasma membranes, which contribute to stability and the biological functions of galectin-3 (36). This property of galectin-3 is targetable. For example, galectin-3C, a truncated form of human galectin-3, functions as an inhibitor of galectin-3 oligomerization and displays a more effective antitumor activity than the intact lectin (37-39).

Galectin-3 lattices are high-order supramolecular structures of the lectin cross-linked with its specific ligands. The most studied galectin-3 ligands are found in $N$-glycans from cell surface or ECM glycoproteins. The amount of $\mathrm{N}$-glycan structures in a given glycoprotein determines the probability of lattice formation, which in turn interferes with biological aspects of the glycoprotein function, such as its endocytosis (receptor turnover) or its ability to transduce signals (40). Through its ability to form glycoprotein lattices, galectin-3 tunes the function of different receptors, such as the epidermal growth factor receptor, platelet-derived growth factor receptor, fibroblast growth receptor, vascular endothelial 
growth factor receptor (VEGFR), and transforming factor- $\beta$ receptor (40-42). It is worth noting that galectin-3 is not always associated with activation of endocytosis of glycoprotein receptors. Indeed, a galectin-3-dependent lattice can lead to persistence of a given receptor on the cell surface. For example, this observation suggests that galectin-3 does not directly determine the process of endocytosis but will be determined by the partners of the galectin-3 ligand on the cell surface.

Galectin-3 is widely distributed among different species and, at the cellular level, it can be found in the extracellular and intracellular milieu (43-45). Hence, galectin-3 can participate in many important biological processes in the cytoplasm and nucleus, where no cognate carbohydrate ligands for galectin-3 are often present. These functions result from protein-protein interactions, showing the versatility of this molecule. Accumulating evidence shows that galectin-3 interacts with a large number of molecules. Based on the distribution of galectin-3 in different subcellular compartments and its ability to interact with different molecules, it has been suggested that galectin- 3 serves as a shuttling protein (46), playing distinct roles in many biological processes depending on its localization. In the nucleus, galectin-3 modulates cell survival and mRNA splicing $(47,48)$. For example, galectin-3 forms complexes with members of the spliceosome mediating pre-mRNA splicing and spliceosome assembly in a carbohydrateindependent manner (49). Despite the absence of glycan ligands in intracellular compartment, electrostatic potential calculations show a linear array of three positively charged arginine residues in a cleft of galectin-3 CRD that suggests a possible binding site to RNA (23). In the same context, intracellular galectin-3 CRD modulates DNA damage response through interacting with BARD1, a BRCA1 partner (50), and attenuates the pro-apoptotic activity of Bax through interaction with members of the bcl-2 family (51-55).

Galectin-3 undergoes posttranslational modifications, such as limited proteolysis and phosphorylation. Extracellular galectin-3 may be cleaved by different molecules, such as matrix metalloproteases (MMPs) and the prostate-specific antigen (PSA). MMPdependent processing leads to its truncated form. As mentioned above, this truncated form of galectin-3 interferes with galectin-3 multimerization and biological functions. Structural variants of galectin-3, due to single nucleotide polymorphisms or phosphorylation at specific sites of full galectin-3, interfere with proteolysis. There are three different single nucleotide polymorphisms in galectin-3 gene distributed in human populations $(56,57)$. For example, the change Pro64 for His64 has been associated with alterations in galectin-3 function and with breast (58) and prostate cancer (59) incidence. In fact, this $\mathrm{P} 64 \mathrm{H}$ substitution is susceptible to MMP-2 and -9 cleavages (60).

Phosphorylation implicates conformational changes of the protein, altering the interaction of galectin-3 with ligands and its ability to participate in multivalent interactions (61-63). Although the physiological significance of this posttranslational modification remains unclear, it has been suggested that phosphorylation of galectin-3 may modulate its intracellular function and translocation. Galectin-3 may be phosphorylated at N-terminal Ser (Ser6 and Ser12) or at Tyr sites (61, 64-66). For example, serine phosphorylation has been associated with differential binding to laminin and mucin, besides playing a role in nuclear export and antiapoptotic activity of galectin-3 (67-69). Tyrosine phosphorylation of galectin-3, mediated by c-Abl kinase, appears to be essential for cell motility, lysosomal degradation, cleavage inhibition, and secretion of galectin-3 (58, 70, 71). However, the mechanisms involved in galectin-3 secretion and its traffic among different organelles in the intracellular compartment are not well-understood. Galectin-3 is unlikely to be secreted by the ER/Golgi pathway since it lacks the classical secretion signal sequence. In fact, few studies suggest alternative mechanisms like vesicular release $(72,73)$, exosomes $(74)$, and even a mechanotransduction-based mechanism (75) for its extracellular secretion. A conceivable possibility in pathophysiological conditions, including cancers, is that part of extracellular galectin-3 is released passively from dying cells. The basic mechanisms for galectin-3 subcellular compartmentalization have been partly unraveled. Galectin-3 lacks a nuclear localization sequence (NLS), and it interacts with components of the nuclear pore complex for its nuclear import-export (76-80). However, the fine control of galectin-3 translocation within subcellular compartments is not clearly understood.

Based on the aforementioned, it is not surprising that galectin-3 is also involved in many pathological conditions like cancer. Indeed, the importance of carbohydrates and lectins in cancer biology can be illustrated by the specific glycosylation signatures found in human tumors (81-84). Besides multiple factors like availability and localization of nucleotide sugar donors and substrates contributing to aberrant glycosylation in cancer, the main mechanism seems to be the differential expression of glycosyltransferases and glycosidases involved in the synthesis and catabolism of glycans (85). Besides changes in glycan sialylation, which interferes with galectin-3-binding as discussed above, cancer cells often present a significant increase in beta1-6 branching in $N$-linked glycans due to increased MGAT5 (UDP- $N$-acetyl-Dglucosamine: $N$-acetylglucosamine transferase $\mathrm{V})$ activity $(81,82)$. MGAT5 overexpression is responsible to enhance metastasis potential in mouse mammary cancer cells (86). Canine mammary tumor cells entering the blood stream accumulate a large amount of galectin-3, which is associated with emboli formation $(15,87)$. Besides altered glycosylation, galectin-3 expression is commonly dysregulated within the tumor microenvironment, either by altered expression in tumor cells or by its expression in infiltrating leukocytes [for a comprehensive list of studies in human tumors, see Ref. (88)].

\section{GALECTIN-3 IN CANCER CELL SIGNALING: A ROLE FOR GALECTIN-3 IN THE TUNING OF CELLULAR STRESS SIGNALING PATHWAYS}

It is well-documented that galectin-3 expression is altered in malignant tissues, and it has many functions in cancer progression, additionally the localization of this molecule is an important feature to understand its function, as already mentioned $(84,89)$. Here, we will discuss the involvement of galectin-3 in stress signaling pathways (MAPK family, from 
mitogen-activated protein kinase) and in the orchestration of both cell and tissue responses in stress conditions commonly found within the tumor microenvironment (Figure 1).
MAPKs are serine-threonine kinases that link extracellular signals with a diversity of cellular processes, such as growth, proliferation, migration, survival, and death (90). Abnormalities
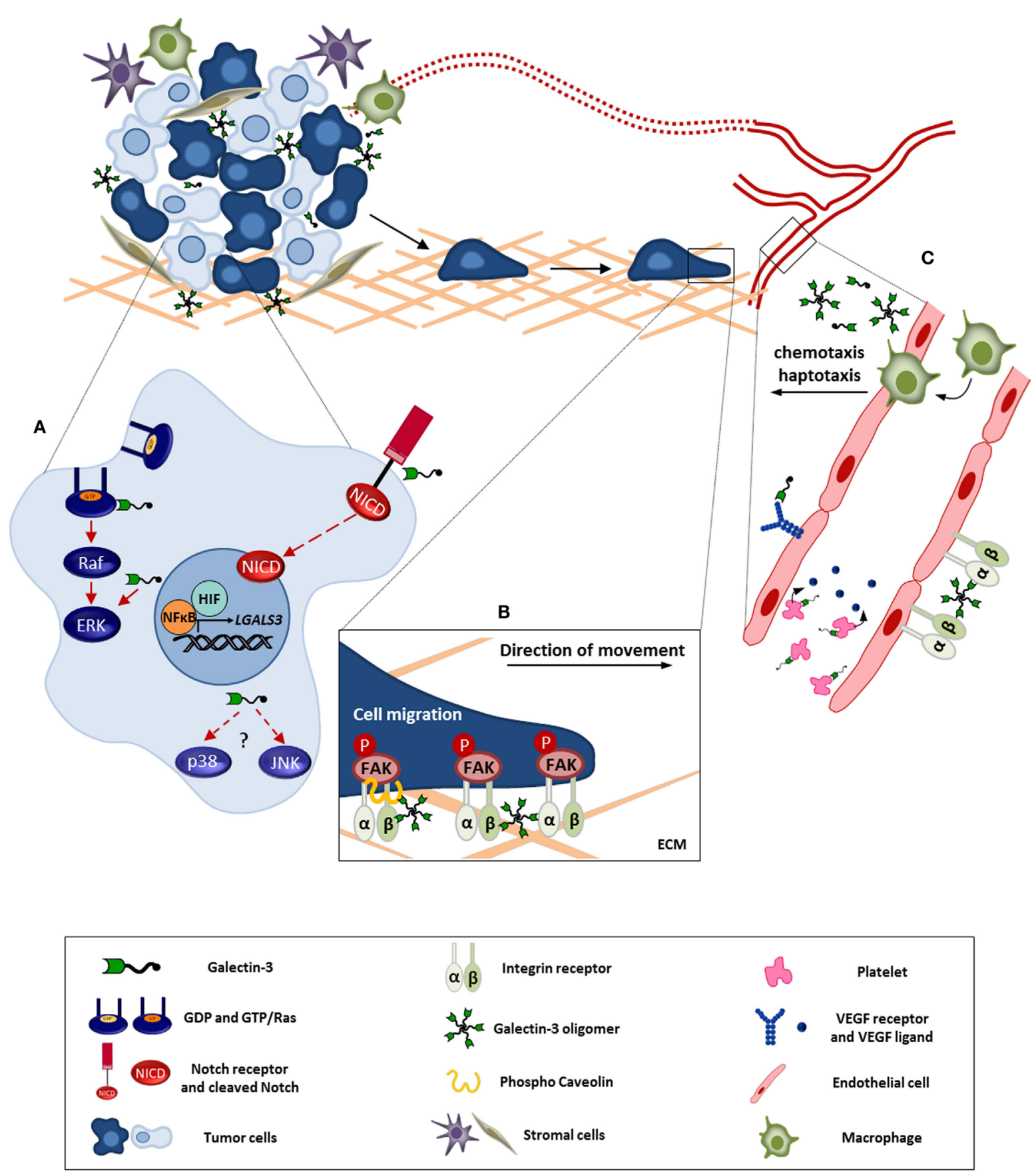

FIGURE 1 | Galectin-3 involvement in tumor progression. This figure represents the intra-and extracellular galectin-3 functions in processes like cell survival, migration, and angiogenesis. (A) In tumor cell, galectin-3 regulates signaling pathways like, Ras/Raf/MEK/ERK and Notch, modulating the cell survival, proliferation, and migration. Besides, NFkB and HIF positively regulate galectin-3 expression contributing to its function within the tumor microenvironment. (B) Extracellular galectin-3 promotes tumor cell migration through interaction with mediators, such as integrins and caveolin, leading to FAK stabilization. (C) Regarding angiogenesis, the full-length galectin-3 can form oligomers and bind to endothelial cell surface, preventing VEGFR and integrin internalization. In addition, galectin-3 induces VEGF release by platelets. Furthermore, galectin-3 promotes monocyte/macrophage chemotaxis toward tumor microenvironment potentializing macrophage-induced angiogenesis. ECM, extracellular matrix. Red full arrows: galectin-3 contributes directly to pathway activation. Red dashed arrows: possible interaction of galectin-3 in described pathway. 
in MAPK signaling play a key role in development and progression of cancer. MAPK family consists of three main groups (i) extracellular signal-regulated kinase (ERK), which is activated by the Ras-Raf-MEK cascade; (ii) p38; and (iii) c-Jun $\mathrm{NH}_{2}$-terminal kinase.

Galectin-3 was first associated with Ras signaling in cancers, as galectin-3 interacts selectively through its CRD with activated K-Ras (K-Ras-GTP) and stabilizes it in the "on" state (91). Activated K-Ras enhances the translocation of galectin-3 to the plasma membrane and thereby galectin-3 increases $\mathrm{K}$-Ras signaling, promoting phosphoinositide 3-kinase (PI3-K) activation and controlling both the intensity and duration of the $\mathrm{K}-\mathrm{Ras}$ signal (Figure 1A). Through this mechanism, galectin-3 and Ras regulate important processes in tumor cells, such as proliferation and survival, playing key roles in different cancer cells (e.g., breast cancer cells). Galectin-3 is necessary for optimal activation of K-Ras/MEK pathway in breast cancer cells (92). It has been proposed that high expression of galectin-3 cooperates with K-Ras transforming activity, leading to the malignant phenotype. Additional data revealed that galectin-3 is an integral component of nanoclusters containing K-Ras, supramolecular structures partitioned into the plasma membrane. Formation of nanoclusters is essential for high fidelity signal transduction, with the ability to increase K-Ras activation to drive tumorigenesis via constitutive activation of Raf/MEK/ERK signaling cascade (93).

Galectin-3 is strongly expressed in thyroid carcinoma cells, but not in benign tumors, and as such, it is associated with the levels of GTP-bound K-Ras, thus contributing to thyroid carcinoma malignancy. Furthermore, the disruption of the interaction between Ras/galectin-3 reduced ERK activation, enhanced the cell cycle inhibitor p21 expression, and inhibited proliferation in vitro and tumor growth in nude mice (94). Song and colleagues investigated the effects of galectin-3 in downstream signaling events to the Ras pathway, using complementary in vitro and in vivo systems in pancreatic carcinogenesis. These studies showed that galectin-3 downregulation leads to decreased activation of AKT and ERK; thus, decreasing cell invasion and reducing tumor growth in an orthotopic mouse model (95). Moreover, in 2008, Saegusa and collaborators had reported that galectin-3 had an antiapoptotic role in keratinocytes treated with etoposide or irradiated with UVB light. In these experiments, keratinocytes devoid of galectin-3 were more susceptible to apoptotic stimuli by altered activation of ERK and reduced activation of AKT (96). The pro-survival role of intracellular galectin-3 and its association with the activation of Ras/Raf/MEK/ERK and the PI3-K/AKT pathways is now clear. Moreover, it has also been shown that galectin-3 enhances the migration of colon cancer cells (97) through activation of the K-Ras-Raf-ERK1/2 pathway (discussed below).

More recent studies have been carried out to understand the interaction of galectin-3 and downstream targets of the MAPK pathway. Gao and colleagues have investigated the roles and mechanisms of circulating galectin-3 in signal transduction, specifically in ERK signaling. Although intracellular galectin-3 increased ERK phosphorylation through RAS activation, Gao found that exogenous galectin-3 may stimulate positively ERK1/2 in a calcium-sensitive and PKC-dependent manner.
Using truncated proteins, they demonstrated that intact extracellular galectin-3 is required to activate ERK1/2 in order to promote cell migration. In this study, AKT signaling was not activated by circulating galectin-3 (98). In another related study, it was observed that binding of galectin-3 to mucin 1 (MUC1), a mucin involved in potentiating growth factor-dependent signal transduction, enhances cell proliferation and motility in different epithelial cancer cells, through activation of both ERK1/2 and AKT pathways. Accordingly, galectin-3-depleted cells grew slowly as compared to the parental galectin-3-expressing cells (99). In sarcoma cells, galectin-3 disrupts focal adhesion plaques, inducing cell migration in an AKT-dependent manner (100).

There are few reports about galectin-3 and its relation with p38 or JNK kinases (Figure 1A). Both kinases are more responsive to stress stimuli than growth factors, comparing with ERK1/2. Thus, when Borges and collaborators investigated the effect of copper complexes in melanoma cells, they demonstrated that the metal treatment increased the levels of intracellular reactive oxygen species (ROS), which was accompanied by $\mathrm{p} 38$ activation in galectin-3-expressing melanoma cells (101). In addition, it has been reported that extracellular galectin-3 induces MMP-9 expression via 38 MAPK pathway in melanoma cells (102). These results show a different function of galectin-3 in p38 regulation, associated with another critical circuitry of the malignant phenotype, invasion, and metastasis. Regarding the JNK kinase family, it is known that intracellular galectin-3 activates elements of the JNK pathway. Evidence exists that the activation of both ERK and JNK1/2 depend on the phosphorylation status of the $\mathrm{Ser}^{6}$ residue of galectin-3. Phosphorylation of galectin-3 by kinases, such as casein kinase, seems necessary to the activation of antiapoptotic circuits dependent on ERK and JNK (68). Although it is known that galectin-3 regulates the activity of MAPK pathway in several cancer models, further studies are still necessary to elucidate the mechanistic details of the pro-survival activity of galectin-3. These studies will be necessary to design targeting strategies for potential clinical interventions.

\section{Galectin-3 Expression Is Regulated by Both NF-kB and HIF}

$\mathrm{NF}-\kappa \mathrm{B}$ is a family of transcription factors that plays important roles in the immune system and regulates the expression of cytokines, cyclo-oxygenase 2 (COX-2), growth factors, and inhibitors of apoptosis. Moreover, pathological dysregulation of $\mathrm{NF}-\kappa \mathrm{B}$ is associated with inflammatory and autoimmune diseases as well as cancer (103). On studying galectin-3 expression in glioblastoma cells exposed to a variety of stressing stimuli, Dumic and colleagues found that NF- $\mathrm{KB}$ inhibition by specific proteasomal inhibitors decreased the expression of galectin-3 (104). In the same way, it was also showed that the interference in NF- $\mathrm{B}$ activation can inhibit galectin-3 expression leading to apoptotic processes (105). We have found a relationship among galectin-3, $\mathrm{NF}-\kappa \mathrm{B}$, hypoxia and nutrient deprivation, and common stressing conditions within the tumor microenvironment. HIF- $1 \alpha$ is a master regulator of gene transcription under hypoxia, upregulating several genes, including galectin-3, in order to maintain cellular homeostasis and promote cell survival in skeletal tissues 
(106). At the tissue level, galectin-3 accumulates in hypoxic/ nutrient-deprived areas from both glioblastoma and mammary tumors (87, 107-109). Under hypoxic conditions, galectin-3 transcription requires protein synthesis and depends on both HIF- $1 \alpha$ and NF- $\kappa B$ activities (Figure 1A). Nuclear translocation of NF- $\mathrm{NB}$ was also induced within hypoxic/nutrient-deprived microenvironments, such as pseudopalisades in glioblastomas (109). Such areas are enriched in galectin-3, which protects cells from death. More recently, another study has shown that galectin-3 deficiency reduces proliferation of hepatoma cells and increases their rate of apoptosis both in vitro and in vivo. Conversely, it was demonstrated that galectin-3 expression induced by NF- $\mathrm{BB}$ transactivation led to a more invasive phenotype of tumor cells, which developed larger tumors as compared to those found in galectin- $3^{-/-}$mice (110).

\section{Galectin-3 and Notch Signaling}

Notch signaling plays a key role in differentiation, survival, and/or proliferation. Alterations in the regulation of these processes contribute to malignant transformation - abnormal activation of this pathway is often found in various types of cancers. Notch signaling pathway involves communication among adjacent cells, one expressing a ligand (either Delta or Jagged) and the other expressing Notch, as a receptor and signal transducer (111). Initially, it was described that galectin-1 increased the expression of Notch1/Jagged2, promoting lung cancer progression (112). Fermino and collaborators then showed that endogenous galectin-3 selectively regulates downstream targets of Notch signaling pathway. Cells devoid of galectin-3 displayed a higher expression of Notch and its target gene HES-1 in an infection model (113). Nakajima and colleagues had described a galectin-3-dependent activation of Notch1 signaling in a system that models tumor cell/osteoblast and osteoclast interactions, critical events in the maintenance of bone metastasis found in different cancers, such as breast and prostate cancers. Using coculture of human fetal osteoblasts (hFOB) with cancer cells expressing galectin-3, these authors showed that galectin-3 secreted by cancer cells inhibited osteoblast differentiation, a Notch1-regulated process. Extracellular galectin-3 interacted with Notch1, in a CRD-dependent manner, activating Notch through its proteolytic cleavage, which leads to the formation of Notch intracellular domain (NICD) with its subsequent translocation to the nucleus leading to Notch target genes upregulation (Figure 1A), which in turn is associated with the maintenance of a non-differentiated state of the osteoblast. In this set of experiments, Nakajima and colleagues also evaluated both intact galectin-3 and a truncated form of galectin- 3 containing primarily its CRD. Although both forms of galectin-3 led to the activation of Notch, results shown apparently indicate that the intact galectin-3 is more efficient in the induction of Notch cleavage than its truncated form. Altogether, these events promoted suppression of osteoblast differentiation and caused bone remodeling in bone metastatic lesions (114). These experiments open a venue for research in a variety of Notch-dependent processes, from maintenance of a non-differentiated state of cells/tumor cells, activation of survival pathways, which in turn lead to resistance to different therapeutic strategies, to the process of angiogenesis.

\section{GALECTIN-3 PROMOTES TUMOR MIGRATION}

Tumor progression is dictated by the bidirectional interaction between tumor and host cells that compose the tumor microenvironment. Besides that, it is also true that the ECM is an important non-cellular component of the tumor microenvironment that interferes with tumor initiation and progression. Based on the fact that galectin-3 can be secreted by cells (either actively or passively) and acts in the extracellular environment either as a monomer or a multimer, forming complexes with other molecules, one might expect that, upon interaction with its specific partners, galectin-3 interferes with different aspects of cancer cell behavior. Here, we will present some examples of how galectin-3 coordinates cellular responses in two critical hallmarks of cancer, tumor cell motility (see Galectin-3 Promotes Tumor Migration) and angiogenesis (see Galectin-3 in Tumor Vasculature).

Recently, Shetty and colleagues observed that galectin-3 promotes cell migration through its association with annexin A2 (AnxA2) on the plasma membrane of HER-2 negative breast cancer cells. This effect was abrogated by tunicamycin, an inhibitor of N-linked glycosylation, and chickpea lectin, a plant lectin highly specific for $N$-acetyl-D-galactosamine of AnxA2, showing that this migratory effect is dependent on galectin-3 CRD domain (115). To gain some insight regarding galectin-3 extracellular function on cell migration, Gao et al. (98) showed that exogenous galectin-3 promoted HeLa cell migration through the activation of ERK 1/2 via a calcium-sensitive and PKC-dependent pathway, which was not abrogated by endogenous galectin-3 knockdown. Moreover, the authors observed that this phenomenon was dependent on both CRD and N-terminal domain of galectin-3. In this context, a specific peptide targeting galectin-3 was able to inhibit prostate cancer cell migration, raising the possibility that galectin-3 inhibitors might avoid tumor spread (116).

Regarding galectin-3 migratory effect, it has been reported that galectin-3 silencing leads to a decrease in cell migration and invasion, through the regulation of different intracellular molecules. In osteosarcoma, this phenomenon was accompanied by a reduction in $\beta$-catenin expression and activation of important mediators of migration and invasion, such as FAK, Src, and Lyn (117). In human tongue cancer cell lines as well as pancreatic cell lines, the reduction of migration and invasion leads to a decrease in $\beta$-catenin, phospho-Akt, GSK-3 $\beta$, and some MMP levels, indicating that galectin-3-mediated migration and invasion involves $\beta$-catenin degradation initiated by Akt phosphorylation in this model (118). In sarcoma cells, a similar trend was observed, as sarcoma cells devoid of galectin-3 were rendered more migratory when exposed to extracellular galectin-3, in a process dependent on the phosphorylation of AKT (100). Other study also indicated the correlation between urokinase-type plasminogen activator receptor (uPAR) levels and galectin-3-decreased migration in hepatocellular carcinoma cells (119). Likewise, Wu et al. (97) showed that overexpression 
of galectin-3 in colon cancer cells induced cell migration, which was correlated with lung colonization in a mouse model.

Again, in a metastatic murine melanoma cell line, B16F10, knocking down of galectin-3 reduced cell migration and invasion as well as MMP-1 levels (120). In vivo, low levels of galectin-3 in B16F10 cells caused a reduction in number of lung metastatic nodules. The authors investigated the molecular mechanism behind this biological effect and found that galectin-3 interacts with the transcriptional factor AP-1, promoting its binding to MMP-1 promoter driving the transcription of this metalloproteinase. In addition, it was also demonstrated that reduced levels of galectin-3 inhibited the binding of both transcription factors c-jun and fra- 1 to the promoter sites of MMP-1. The interaction of intracellular galectin-3 and AP-1 was also described a year earlier in gastric cancer (121). In this study, the authors showed that the complex formed by galectin- 3 and AP- 1 binds to PAR- 1 promoter driving its transcription, which was essential for galectin-3-mediated cell migration and invasion. Moreover, the role of MMP-1 in this phenomenon was pointed out, since its silencing caused a decrease in galectin-3-mediated cell migration.

Galectin-3 also regulates tumor cell migration through other mechanisms (Figure 1B). Exogenous galectin-3, through its ability to form lattices on the cell surface, restored FAK stabilization and cell motility in galectin-3 knockdown cancer cells (122). Lattice formation depends on the density of the glycosylated galectin-3 ligands found on the membrane and on the state of multimerization of galectin-3. Lattices form spatial plasma membrane subdomains, and together with lipid rafts and caveolin-dependent domains, are crucial for the spatial organization of signaling molecules. For example, galectin- 3 and phosphorylated caveolin-1 act synergistically to promote EGFinduced RhoA activation and Mgat $5^{+/+}$cell migration (123). The intracellular phosphorylated form of caveolin-1 activates focal adhesion kinase (84). Boscher and Nabi (123) observed that EGF promoted MDA-MB-231 breast cancer cell migration in a phosphocaveolin-1 and galectin-3-dependent manner, enabling the metastatic spread of these cells.

Additionally, it was demonstrated that the synergistic action of galectin- 3 and caveolin- 1 induced focal adhesion turnover and migration of differentiated thyroid cancer cells (124). Galectin-3 also promotes the raft-dependent endocytosis of integrins and plays a role in cell-matrix interaction (123). In this context, a novel function of galectin-3 has been reported related to the regulation of cell surface receptors by constitutive endocytosis. Specifically, Lakshminarayan and colleagues showed that both glycosphingolipids and extracellular galectin-3 mediate clathrinindependent carriers (CLICs)-dependent endocytosis. This work also reported that galectin-3 is critical for CD44 and $\beta 1$-integrin endocytosis (125). In an intracellular context, Liu and collaborators reported that the absence of galectin-3 impairs keratinocyte migration, and this phenomenon was associated with the function of galectin-3 in the control of intracellular trafficking and cell surface expression of EGFR after EGF stimulation (126). Recently, another study demonstrated that galectin-3 knockdown potentiates the response to gefitinib (EGFR-tyrosine kinase inhibitor) treatment in esophageal squamous cancer cells, a type of cancer that overexpresses EGFR. The absence of galectin-3 impairs the EGFR endocytosis, which enhanced the antitumor effect in gefitinib-insensitive cells like cell viability, cell cycle, and invasion (127). Otherwise, Mazurek and collaborators observed that the silencing of galectin-3 restores tumor necrosis factor-related apoptosis-inducing ligand (TRAIL) sensitivity and promotes TRAIL-mediated endocytosis of TRAIL/death receptors. Thus, galectin-3 impairs TRAIL trafficking by anchoring them in cell membrane surface and blocks the execution of the apoptosis signal (128). Therefore, through regulation of endocytosis and intracellular trafficking of glycoproteins like integrins, galectin-3 assumes a novel role in the control of tumor cell adhesion and migration.

\section{GALECTIN-3 IN TUMOR VASCULATURE}

The successful growth of a tumor mass - either a primary tumor or its metastasis - requires the establishment of an adequate blood supply, frequently, but not exclusively, achieved by the formation of new blood vessels. From premalignant to malignant lesions, the transition between an avascular to a vascular phase is required. Such transition is dictated by the balance of pro- and antiangiogenic signals. Therefore, the angiogenic switch activation requires the secretion of proangiogenic factors produced by both tumor and stromal cells within the tumor microenvironment (129).

Angiogenesis is characterized by a series of endothelial cell responses to this angiogenic balance, which include ECM degradation and budding, proliferation, migration, and tube formation of endothelial cells (130). Major signaling pathways orchestrating this process include VEGFR and fibroblastic growth factor receptor (FGFR) signaling pathways and Notch-dependent pathways (131-133). As mentioned earlier, extracellular galectin-3 is described to act at membrane proteins clusters through lattice formation $(33,134)$, promoting homotypic and heterotypic interactions and regulating substratum adhesion and receptor dynamics at the plasma membrane $(135,136)$.

Through its ability to form supramolecular structures through multimerization and through binding to glycoproteins that display multiple binding sites, galectin-3 serves as a scaffold protein that organizes signaling platforms on the cell surface of endothelial cells. In this sense, galectin-3 acts a cofactor responsible for modulating the angiogenic process, through amplification of the signal triggered by its partners in the context of the lattice formed on the cell surface. Galectin-3 binds directly on human umbilical vein endothelial cell (HUVEC) surface, amplifying the chemotactic response of these cells, besides the induction of capillary tube formation in vitro and angiogenesis in vivo (137). Galectin-3 is also required for the stabilization of epithelial-endothelial interaction networks, an essential process during angiogenesis (138). In vivo, endothelial cells present within tumors are enriched in galectin-3 ligands (13). Indeed, optimal vascularization of tumors was observed in model systems, where both tumor cells and stromal cells express galectin-3 (139). Markowska and colleagues demonstrated that galectin-3 promotes angiogenesis by interacting via CRD with complex $N$-glycans on $\alpha v \beta 3$ integrin and through the activation of FAK-mediated signaling pathways that influence both VEGF and bFGF angiogenic activity. The same group also reported 
that galectin-3 contributes to the plasma membrane retention of VEGFR2, leading to increased angiogenic response to VEGF-A (42) (Figure 1C). A similar effect was observed when galectin-3 was used in combination with galectin-1 and both galectins retained VEGFR1 and VEGFR2 on the plasma membrane, enhancing endothelial cell growth and tube formation (140).

It is still a matter of debate to what extent the ability of galectin-3 to interfere with angiogenesis depends on its posttranslational processing. It is already known that galectin-3 collagen-like N-terminal domain is susceptible to extracellular cleavage in vitro and in vivo by MMP-2 and MMP-9 $(60,141)$. Cleaved galectin-3 displays $\sim 20$-fold higher affinity for endothelial cells (138), incrementing chemotaxis, invasion, and homotypic adhesion resulting in increased angiogenesis (142), as compared with the intact form of the lectin. The $\mathrm{N}$-terminal domain is necessary for optimal oligomerization of galectin-3 $(33,143)$; however, it is conceivable that the collagen-like fraction retained after cleavage by MMPs is still sufficient for some degree of galectin-3 oligomerization.

Besides its direct role in endothelial cells, galectin-3 also influences migration of monocytes/macrophages (144) and their activation (145). Tumor-associated macrophages, which express galectin-3, have been shown to act in tumor angiogenesis and vessel maturation in a density- and phenotype-dependent manner $(146,147)$. Experiments performed by our group showed increased levels of active transforming growth factor $\beta 1$ (TGF $\beta 1$ ) homodimer in galectin-3-expressing tumors (139). TGF $\beta 1$ is reported to induce chemotaxis and VEGF release by human monocytes/macrophages $(148,149)$. Bone marrow-derived macrophages (BMDMs) from galectin-3 KO mice showed a reduced basal secretion of VEGF when compared with BMDMs from WT mice. Upon TGF $\beta 1$ stimulation, WT-BMDMs secreted higher amounts of VEGF, as compared with KO-BMDMs (139). Galectin-3 targets not only macrophages but also platelets (Figure 1C), which release VEGF upon activation through a PKC-dependent pathway (150).

In addition to angiogenesis, galectin- 3 has also been shown to participate in other process required to constitute the tumor vasculature, a process named vasculogenic mimicry. This process is characterized by the functional plasticity of aggressive tumor cells that behave as an endothelial cell in tumor vessels $(151,152)$. It has been proposed that galectin-3 expression in melanoma cells is necessary for their ability to form tube-like structures on collagen type I matrix. Gene expression signatures of galectin-3 deficient cells, as compared to their galectin-3-expressing parental cells, indicated co-expression of galectin-3 with a variety of endothelial cell markers that are involved in tumor angiogenesis, endothelial cell differentiation, and therefore in the process of vasculogenic mimicry (153). Understanding the mechanisms underlying this phenomenon will be necessary for future interventions.

\section{CONCLUDING REMARKS}

Galectin-3 expression is dysregulated in different cancers. Its expression varies within different areas of tumors. For example, stressing conditions, such as hypoxia and nutrient deprivation, induce galectin-3 expression in breast cancer and glioblastoma. Under these conditions, accumulation of galectin-3 in the cytoplasm favors cell survival. Although the mechanistic details of this antiapoptotic activity of galectin-3 are not completely understood, there is accumulating evidence that galectin-3 tunes the different families of MAPKs. An interesting paradigm for galectin-3 function is the formation of nanoclusters with signaling molecules, such as K-RAS. In this context, galectin-3 serves as a scaffold protein, favoring the spatial organization of a signal transducer partitioned into the plasma membrane, where the interaction with other proteins is required for the efficient transduction of cellular signals. Secretion of galectin-3, either active through exosomes or other forms of protein release from the cytoplasm or passive through cell lysis or increased permeability of a dying cell, allows for novel functions of galectin-3, dependent on the extracellular ligand (growth factor receptors, integrins, and cadherins, among other glycoproteins). On the cell surface, the interaction of galectin-3 with glycoproteins illustrates the formation lectin lattices, another example of its scaffold function in the organization of supramolecular structures that interfere with receptor-triggered signal transduction. Extracellular galectin-3 is involved with cell migration (tumor cell, endothelial cell, and leukocyte migration) and the formation of vessels. At this level, secreted galectin-3 plays a homeostatic role in stressed microenvironments, as it induces formation of vessels that support normalization of both oxygen and nutrient delivery to tissues. In tumors, such homeostatic role would support tumor progression (Figure 1), and therefore it is a natural target for intervention. Galectin-3 is also an important modifier of immune cell function, which will constitute now another layer of complexity in its roles in cancer progression, which will be dealt with in other reviews in this series.

\section{AUTHOR CONTRIBUTIONS}

$\mathrm{AC}, \mathrm{LA}, \mathrm{SB}$, and $\mathrm{RC}$ contributed in the idealization of the topic, critical reading of the references, discussion, and writing.

\section{ACKNOWLEDGMENTS}

We thank all members of the Group of Cell Adhesion and Cancer, Instituto do Câncer do Estado de São Paulo, Faculdade de Medicina da Universidade de São Paulo, who contributed to the work cited herein. We thank Fu-Tong Liu and Robert J. Gillies for active discussions. We thank the Brazilian Funding Agencies FAPESP, CNPq, and CAPES for financial support.

\section{FUNDING}

We thank the Brazilian Funding Agencies FAPESP (2013/06120-8), CNPq, and CAPES for financial support. Part of the work was funded by the Consortium for Functional Glycomics, NIH/ NIGMS. 


\section{REFERENCES}

1. Gabius HJ, Siebert HC, André S, Jiménez-Barbero J, Rüdiger H. Chemical biology of the sugar code. Chembiochem (2004) 5:740-64. doi:10.1002/ cbic. 200300753

2. Sharon N, Lis H. History of lectins: from hemagglutinins to biological recognition molecules. Glycobiology (2004) 14:53R-62R. doi:10.1093/glycob/ cwh122

3. Barondes SH, Cooper DN, Gitt MA, Leffler H. Galectins. Structure and function of a large family of animal lectins. J Biol Chem (1994) 269:20807-10.

4. Boscher C, Dennis JW, Nabi IR. Glycosylation, galectins and cellular signaling. Curr Opin Cell Biol (2011) 23:383-92. doi:10.1016/j.ceb.2011.05.001

5. Yang RY, Rabinovich GA, Liu FT. Galectins: structure, function and therapeutic potential. Expert Rev Mol Med (2008) 10:e17. doi:10.1017/ S1462399408000719

6. Agrwal N, Sun Q, Wang SY, Wang JL. Carbohydrate-binding protein 35 . I. Properties of the recombinant polypeptide and the individuality of the domains. J Biol Chem (1993) 268:14932-9.

7. Raimond J, Zimonjic DB, Mignon C, Mattei M, Popescu NC, Monsigny $\mathrm{M}$, et al. Mapping of the galectin-3 gene (LGALS3) to human chromosome 14 at region 14q21-22. Mamm Genome (1997) 8:706-7. doi:10.1007/ s003359900548

8. Kadrofske MM, Openo KP, Wang JL. The human LGALS3 (galectin-3) gene: determination of the gene structure and functional characterization of the promoter. Arch Biochem Biophys (1998) 349:7-20. doi:10.1006/ abbi.1997.0447

9. Ruebel KH, Jin L, Qian X, Scheithauer BW, Kovacs K, Nakamura N, et al. Effects of DNA methylation on galectin-3 expression in pituitary tumors. Cancer Res (2005) 65:1136-40. doi:10.1158/0008-5472.CAN-04-3578

10. Sato S, Hughes RC. Binding specificity of a baby hamster kidney lectin for $\mathrm{H}$ type I and II chains, polylactosamine glycans, and appropriately glycosylated forms of laminin and fibronectin. J Biol Chem (1992) 267:6983-90.

11. Barboni EA, Bawumia S, Henrick K, Hughes RC. Molecular modeling and mutagenesis studies of the $\mathrm{N}$-terminal domains of galectin-3: evidence for participation with the C-terminal carbohydrate recognition domain in oligosaccharide binding. Glycobiology (2000) 10:1201-8. doi:10.1093/ glycob/10.11.1201

12. Ideo H, Matsuzaka T, Nonaka T, Seko A, Yamashita K. Galectin-8-N-domain recognition mechanism for sialylated and sulfated glycans. JBiol Chem (2011) 286:11346-55. doi:10.1074/jbc.M110.195925

13. de Melo FH, Butera D, Medeiros RS, Andrade LN, Nonogaki S, Soares FA, et al. Biological applications of a chimeric probe for the assessment of galectin-3 ligands. J Histochem Cytochem (2007) 55:1015-26. doi:10.1369/ jhc.7A7174.2007

14. Zhuo Y, Chammas R, Bellis SL. Sialylation of beta1 integrins blocks cell adhesion to galectin-3 and protects cells against galectin-3-induced apoptosis. J Biol Chem (2008) 283:22177-85. doi:10.1074/jbc.M8000015200

15. de Oliveira JT, de Matos AJ, Santos AL, Pinto R, Gomes J, Hespanhol V, et al. Sialylation regulates galectin-3/ligand interplay during mammary tumour progression - a case of targeted uncloaking. Int J Dev Biol (2011) 55:823-34. doi:10.1387/ijdb.113359jt

16. Krzeminski M, Singh T, André S, Lensch M, Wu AM, Bonvin AM, et al. Human galectin-3 (Mac-2 antigen): defining molecular switches of affinity to natural glycoproteins, structural and dynamic aspects of glycan binding by flexible ligand docking and putative regulatory sequences in the proximal promoter region. Biochim Biophys Acta (2011) 1810:150-61. doi:10.1016/j. bbagen.2010.11.001

17. Suzuki O, Abe M, Hashimoto Y. Sialylation and glycosylation modulate cell adhesion and invasion to extracellular matrix in human malignant lymphoma: dependency on integrin and the Rho GTPase family. Int J Oncol (2015) 47:2091-9. doi:10.3892/ijo.2015.3211

18. Guardia CM, Gauto DF, Di Lella S, Rabinovich GA, Martí MA, Estrin DA. An integrated computational analysis of the structure, dynamics, and ligand binding interactions of the human galectin network. J Chem Inf Model (2011) 51:1918-30. doi:10.1021/ci200180h

19. Vokhmyanina OA, Rapoport EM, André S, Severov VV, Ryzhov I, Pazynina $\mathrm{GV}$, et al. Comparative study of the glycan specificities of cell-bound human tandem-repeat-type galectin-4, -8 and -9. Glycobiology (2012) 22:1207-17. doi:10.1093/glycob/cws079
20. Kumar S, Frank M, Schwartz-Albiez R. Understanding the specificity of human galectin-8C domain interactions with its glycan ligands based on molecular dynamics simulations. PLoS One (2013) 8:e59761. doi:10.1371/ journal.pone.0059761

21. Lobsanov YD, Gitt MA, Leffler H, Barondes SH, Rini JM. X-ray crystal structure of the human dimeric S-Lac lectin, L-14-II, in complex with lactose at 2.9-A resolution. J Biol Chem (1993) 268:27034-8.

22. Liao DI, Kapadia G, Ahmed H, Vasta GR, Herzberg O. Structure of S-lectin, a developmentally regulated vertebrate beta-galactoside-binding protein. Proc Natl Acad Sci U S A (1994) 91:1428-32. doi:10.1073/pnas.91.4.1428

23. Seetharaman J, Kanigsberg A, Slaaby R, Leffler H, Barondes SH, Rini JM. $\mathrm{X}$-ray crystal structure of the human galectin-3 carbohydrate recognition domain at 2.1-A resolution. J Biol Chem (1998) 273:13047-52. doi:10.1074/ jbc.273.21.13047

24. André S, Lahmann M, Gabius HJ, Oscarson S. Glycocluster design for improved avidity and selectivity in blocking human lectin/plant toxin binding to glycoproteins and cells. Mol Pharm (2010) 7:2270-9. doi:10.1021/ mp1002416

25. André S, Wang GN, Gabius HJ, Murphy PV. Combining glycocluster synthesis with protein engineering: an approach to probe into the significance of linker length in a tandem-repeat-type lectin (galectin-4). Carbohydr Res (2014) 389:25-38. doi:10.1016/j.carres.2013.12.024

26. Halimi H, Rigato A, Byrne D, Ferracci G, Sebban-Kreuzer C, Elantak L, et al. Glycan dependence of galectin-3 self-association properties. PLoS One (2014) 9:e111836. doi:10.1371/journal.pone.0111836

27. Hsu DK, Zuberi RI, Liu FT. Biochemical and biophysical characterization of human recombinant IgE-binding protein, an S-type animal lectin. J Biol Chem (1992) 267:14167-74

28. Mehul B, Bawumia S, Martin SR, Hughes RC. Structure of baby hamster kidney carbohydrate-binding protein CBP30, an S-type animal lectin. J Biol Chem (1994) 269:18250-8

29. Kuklinski S, Probstmeier R. Homophilic binding properties of galectin-3: involvement of the carbohydrate recognition domain. J Neurochem (1998) 70:814-23. doi:10.1046/j.1471-4159.1998.70020814.x

30. Ochieng J, Green B, Evans S, James O, Warfield P. Modulation of the biological functions of galectin-3 by matrix metalloproteinases. Biochim Biophys Acta (1998) 1379:97-106. doi:10.1016/S0304-4165(97)00086-X

31. Birdsall B, Feeney J, Burdett ID, Bawumia S, Barboni EA, Hughes RC. NMR solution studies of hamster galectin-3 and electron microscopic visualization of surface-adsorbed complexes: evidence for interactions between the N- and C-terminal domains. Biochemistry (2001) 40:4859-66. doi:10.1021/ bi002907f

32. Hernandez JD, Baum LG. Ah, sweet mystery of death! Galectins and control of cell fate. Glycobiology (2002) 12:127R-36R. doi:10.1093/glycob/cwf081

33. Ahmad N, Gabius HJ, André S, Kaltner H, Sabesan S, Roy R, et al. Galectin-3 precipitates as a pentamer with synthetic multivalent carbohydrates and forms heterogeneous cross-linked complexes. J Biol Chem (2004) 279:10841-7. doi:10.1074/jbc.M312834200

34. Leffler H, Carlsson S, Hedlund M, Qian Y, Poirier F. Introduction to galectins. Glycoconj J (2004) 19:433-40. doi:10.1023/B:GLYC.0000014072.34840.04

35. Morris S, Ahmad N, André S, Kaltner H, Gabius HJ, Brenowitz M, et al. Quaternary solution structures of galectins-1, -3, and -7. Glycobiology (2004) 14:293-300. doi:10.1093/glycob/cwh029

36. Rabinovich GA, Toscano MA, Jackson SS, Vasta GR. Functions of cell surface galectin-glycoprotein lattices. Curr Opin Struct Biol (2007) 17:513-20. doi:10.1016/j.sbi.2007.09.002

37. John CM, Leffler H, Kahl-Knutsson B, Svensson I, Jarvis GA. Truncated galectin-3 inhibits tumor growth and metastasis in orthotopic nude mouse model of human breast cancer. Clin Cancer Res (2003) 9:2374-83.

38. Mirandola L, Yu Y, Chui K, Jenkins MR, Cobos E, John CM, et al. Galectin-3C inhibits tumor growth and increases the anticancer activity of bortezomib in a murine model of human multiple myeloma. PLoS One (2011) 6:e21811. doi:10.1371/journal.pone.0021811

39. Mirandola L, Nguyen DD, Rahman RL, Grizzi F, Yuefei Y, Figueroa JA, et al. Anti-galectin-3 therapy: a new chance for multiple myeloma and ovarian cancer? Int Rev Immunol (2014) 33:417-27. doi:10.3109/08830185 2014.911855

40. Lau KS, Partridge EA, Grigorian A, Silvescu CI, Reinhold VN, Demetriou M, et al. Complex N-glycan number and degree of branching cooperate to 
regulate cell proliferation and differentiation. Cell (2007) 129:123-34. doi:10.1016/j.cell.2007.01.049

41. Partridge EA, Le Roy C, Di Guglielmo GM, Pawling J, Cheung P, Granovsky $\mathrm{M}$, et al. Regulation of cytokine receptors by Golgi N-glycan processing and endocytosis. Science (2004) 306:120-4. doi:10.1126/science.1102109

42. Markowska AI, Jefferies KC, Panjwani N. Galectin-3 protein modulates cell surface expression and activation of vascular endothelial growth factor receptor 2 in human endothelial cells. J Biol Chem (2011) 286:29913-21. doi:10.1074/jbc.M111.226423

43. Moutsatsos IK, Wade M, Schindler M, Wang JL. Endogenous lectins from cultured cells: nuclear localization of carbohydrate-binding protein 35 in proliferating 3T3 fibroblasts. Proc Natl Acad Sci U S A (1987) 84:6452-6. doi:10.1073/pnas.84.18.6452

44. Gaudin JC, Mehul B, Hughes RC. Nuclear localisation of wild type and mutant galectin-3 in transfected cells. Biol Cell (2000) 92:49-58. doi:10.1016/ S0248-4900(00)88763-8

45. Openo KP, Kadrofske MM, Patterson RJ, Wang JL. Galectin-3 expression and subcellular localization in senescent human fibroblasts. Exp Cell Res (2000) 255:278-90. doi:10.1006/excr.1999.4782

46. Davidson PJ, Davis MJ, Patterson RJ, Ripoche MA, Poirier F, Wang JL. Shuttling of galectin-3 between the nucleus and cytoplasm. Glycobiology (2002) 12:329-37. doi:10.1093/glycob/12.5.329

47. Liu FT, Patterson RJ, Wang JL. Intracellular functions of galectins. Biochim Biophys Acta (2002) 1572:263-73. doi:10.1016/S0304-4165(02)00313-6

48. Patterson RJ, Haudek KC, Voss PG, Wang JL. Examination of the role of galectins in pre-mRNA splicing. Methods Mol Biol (2015) 1207:431-49. doi:10.1007/978-1-4939-1396-1_28

49. Park JW, Voss PG, Grabski S, Wang JL, Patterson RJ. Association of galectin-1 and galectin-3 with Gemin4 in complexes containing the SMN protein. Nucleic Acids Res (2001) 29:3595-602. doi:10.1093/nar/29.17.3595

50. Carvalho RS, Fernandes VC, Nepomuceno TC, Rodrigues DC, Woods NT, Suarez-Kurtz G, et al. Characterization of LGALS3 (galectin-3) as a player in DNA damage response. Cancer Biol Ther (2014) 15:840-50. doi:10.4161/ cbt. 28873

51. Yang RY, Hsu DK, Liu FT. Expression of galectin-3 modulates T-cell growth and apoptosis. Proc Natl Acad Sci U S A (1996) 93:6737-42. doi:10.1073/ pnas.93.13.6737

52. Akahani S, Nangia-Makker P, Inohara H, Kim HR, Raz A. Galectin-3: a novel antiapoptotic molecule with a functional BH1 (NWGR) domain of Bcl-2 family. Cancer Res (1997) 57:5272-6.

53. Yoshii T, Fukumori T, Honjo Y, Inohara H, Kim HR, Raz A. Galectin-3 phosphorylation is required for its anti-apoptotic function and cell cycle arrest. J Biol Chem (2002) 277:6852-7. doi:10.1074/jbc.M107668200

54. Fukumori T, Oka N, Takenaka Y, Nangia-Makker P, Elsamman E, Kasai T, et al. Galectin-3 regulates mitochondrial stability and antiapoptotic function in response to anticancer drug in prostate cancer. Cancer Res (2006) 66:3114-9. doi:10.1158/0008-5472.CAN-05-3750

55. Harazono Y, Kho DH, Balan V, Nakajima K, Zhang T, Hogan V, et al. Galectin-3 leads to attenuation of apoptosis through Bax heterodimerization in human thyroid carcinoma cells. Oncotarget (2014) 5:9992-10001. doi:10.18632/oncotarget.2486

56. Poirier O, Nicaud V, Vionnet N, Raoux S, Tarnow L, Vlassara H, et al. Polymorphism screening of four genes encoding advanced glycation end-product putative receptors. Association study with nephropathy in type 1 diabetic patients. Diabetes (2001) 50:1214-8. doi:10.2337/ diabetes.50.5.1214

57. Martins L, Leoni SG, Friguglietti CU, Ward LS, Kulcsar MA, Kimura ET. [Polymorphism on codon 98 of the galectin-3 gene is not associated to benign and malignant thyroid tumors]. Arq Bras Endocrinol Metabol (2006) 50:1075-81. doi:10.1590/S0004-27302006000600014

58. Balan V, Nangia-Makker P, Kho DH, Wang Y, Raz A. Tyrosine-phosphorylated galectin-3 protein is resistant to prostate-specific antigen (PSA) cleavage. J Biol Chem (2012) 287:5192-8. doi:10.1074/jbc.C111.331686

59. Meyer A, Coinac I, Bogdanova N, Dubrowinskaja N, Turmanov N, Haubold $\mathrm{S}$, et al. Apoptosis gene polymorphisms and risk of prostate cancer: a hospital-based study of German patients treated with brachytherapy. Urol Oncol (2013) 31:74-81. doi:10.1016/j.urolonc.2010.09.011

60. Ochieng J, Fridman R, Nangia-Makker P, Kleiner DE, Liotta LA, StetlerStevenson WG, et al. Galectin-3 is a novel substrate for human matrix metalloproteinases-2 and -9. Biochemistry (1994) 33:14109-14. doi:10.1021/ bi00251a020

61. Huflejt ME, Turck CW, Lindstedt R, Barondes SH, Leffler H. L-29, a soluble lactose-binding lectin, is phosphorylated on serine 6 and serine 12 in vivo and by casein kinase I. J Biol Chem (1993) 268:26712-8.

62. Mazurek N, Conklin J, Byrd JC, Raz A, Bresalier RS. Phosphorylation of the beta-galactoside-binding protein galectin-3 modulates binding to its ligands. J Biol Chem (2000) 275:36311-5. doi:10.1074/jbc.M003831200

63. Berbís M, André S, Cañada FJ, Pipkorn R, Ippel H, Mayo KH, et al. Peptides derived from human galectin-3 N-terminal tail interact with its carbohydrate recognition domain in a phosphorylation-dependent manner. Biochem Biophys Res Commun (2014) 443:126-31. doi:10.1016/j.bbrc.2013.11.063

64. Cowles EA, Agrwal N, Anderson RL, Wang JL. Carbohydrate-binding protein 35 . Isoelectric points of the polypeptide and a phosphorylated derivative. J Biol Chem (1990) 265:17706-12.

65. Gong HC, Honjo Y, Nangia-Makker P, Hogan V, Mazurak N, Bresalier RS, et al. The NH2 terminus of galectin-3 governs cellular compartmentalization and functions in cancer cells. Cancer Res (1999) 59:6239-45.

66. Menon RP, Hughes RC. Determinants in the N-terminal domains of galectin-3 for secretion by a novel pathway circumventing the endoplasmic reticulum-Golgi complex. Eur J Biochem (1999) 264:569-76. doi:10.1046/j.1432-1327.1999.00671.x

67. Tsay YG, Lin NY, Voss PG, Patterson RJ, Wang JL. Export of galectin-3 from nuclei of digitonin-permeabilized mouse 3T3 fibroblasts. Exp Cell Res (1999) 252:250-61. doi:10.1006/excr.1999.4643

68. Takenaka Y, Fukumori T, Yoshii T, Oka N, Inohara H, Kim HR, et al. Nuclear export of phosphorylated galectin-3 regulates its antiapoptotic activity in response to chemotherapeutic drugs. Mol Cell Biol (2004) 24:4395-406. doi:10.1128/MCB.24.10.4395-4406.2004

69. Haudek KC, Spronk KJ, Voss PG, Patterson RJ, Wang JL, Arnoys EJ. Dynamics of galectin-3 in the nucleus and cytoplasm. Biochim Biophys Acta (2010) 1800:181-9. doi:10.1016/j.bbagen.2009.07.005

70. Li X, Ma Q, Wang J, Liu X, Yang Y, Zhao H, et al. c-Abl and Arg tyrosine kinases regulate lysosomal degradation of the oncoprotein galectin-3. Cell Death Differ (2010) 17:1277-87. doi:10.1038/cdd.2010.8

71. Menon S, Kang CM, Beningo KA. Galectin-3 secretion and tyrosine phosphorylation is dependent on the calpain small subunit, Calpain 4. Biochem Biophys Res Commun (2011) 410:91-6. doi:10.1016/j.bbrc.2011.05.112

72. Sato S, Burdett I, Hughes RC. Secretion of the baby hamster kidney $30-\mathrm{kDa}$ galactose-binding lectin from polarized and nonpolarized cells: a pathway independent of the endoplasmic reticulum-Golgi complex. Exp Cell Res (1993) 207:8-18. doi:10.1006/excr.1993.1157

73. Mehul B, Hughes RC. Plasma membrane targetting, vesicular budding and release of galectin 3 from the cytoplasm of mammalian cells during secretion. J Cell Sci (1997) 110(Pt 10):1169-78.

74. Théry C, Boussac M, Véron P, Ricciardi-Castagnoli P, Raposo G, Garin J, et al. Proteomic analysis of dendritic cell-derived exosomes: a secreted subcellular compartment distinct from apoptotic vesicles. J Immunol (2001) 166:7309-18. doi:10.4049/jimmunol.166.12.7309

75. Baptiste TA, James A, Saria M, Ochieng J. Mechano-transduction mediated secretion and uptake of galectin-3 in breast carcinoma cells: implications in the extracellular functions of the lectin. Exp Cell Res (2007) 313:652-64. doi:10.1016/j.yexcr.2006.11.005

76. Davidson PJ, Li SY, Lohse AG, Vandergaast R, Verde E, Pearson A, et al. Transport of galectin-3 between the nucleus and cytoplasm. I. Conditions and signals for nuclear import. Glycobiology (2006) 16:602-11. doi:10.1093/ glycob/cwj088

77. Li SY, Davidson PJ, Lin NY, Patterson RJ, Wang JL, Arnoys EJ. Transport of galectin-3 between the nucleus and cytoplasm. II. Identification of the signal for nuclear export. Glycobiology (2006) 16:612-22. doi:10.1093/ glycob/cwj089

78. Nakahara S, Oka N, Wang Y, Hogan V, Inohara H, Raz A. Characterization of the nuclear import pathways of galectin-3. Cancer Res (2006) 66:9995-10006. doi:10.1158/0008-5472.CAN-06-1772

79. Funasaka T, Raz A, Nangia-Makker P. Nuclear transport of galectin-3 and its therapeutic implications. Semin Cancer Biol (2014) 27:30-8. doi:10.1016/j. semcancer.2014.03.004

80. Arnoys EJ,Ackerman CM, WangJL. Nucleocytoplasmic shuttling ofgalectin-3. Methods Mol Biol (2015) 1207:465-83. doi:10.1007/978-1-4939-1396-1_30 
81. Dennis JW, Granovsky M, Warren CE. Glycoprotein glycosylation and cancer progression. Biochim Biophys Acta (1999) 1473:21-34. doi:10.1016/ S0304-4165(99)00167-1

82. Granovsky M, Fata J, Pawling J, Muller WJ, Khokha R, Dennis JW. Suppression of tumor growth and metastasis in Mgat5-deficient mice. Nat Med (2000) 6:306-12. doi:10.1038/73163

83. Pinho SS, Reis CA. Glycosylation in cancer: mechanisms and clinical implications. Nat Rev Cancer (2015) 15:540-55. doi:10.1038/nrc3982

84. Ruvolo PP. Galectin 3 as a guardian of the tumor microenvironment. Biochim Biophys Acta (2016) 1863:427-37. doi:10.1016/j.bbamcr.2015.08.008

85. Meany DL, Chan DW. Aberrant glycosylation associated with enzymes as cancer biomarkers. Clin Proteomics (2011) 8:7. doi:10.1186/1559-0275-8-7

86. Seberger PJ, Chaney WG. Control of metastasis by Asn-linked, beta1-6 branched oligosaccharides in mouse mammary cancer cells. Glycobiology (1999) 9:235-41. doi:10.1093/glycob/9.3.235

87. de Oliveira JT, Ribeiro C, Barros R, Gomes C, de Matos AJ, Reis CA, et al. Hypoxia up-regulates galectin- 3 in mammary tumor progression and metastasis. PLoS One (2015) 10:e0134458. doi:10.1371/journal.pone.0134458

88. Wang L, Guo XL. Molecular regulation of galectin-3 expression and therapeutic implication in cancer progression. Biomed Pharmacother (2016) 78:165-71. doi:10.1016/j.biopha.2016.01.014

89. Thijssen VL, Heusschen R, Caers J, Griffioen AW. Galectin expression in cancer diagnosis and prognosis: a systematic review. Biochim Biophys Acta (2015) 1855:235-47. doi:10.1016/j.bbcan.2015.03.003

90. Kim EK, Choi EJ. Pathological roles of MAPK signaling pathways in human diseases. Biochim Biophys Acta (2010) 1802:396-405. doi:10.1016/j. bbadis.2009.12.009

91. Elad-Sfadia G, Haklai R, Balan E, Kloog Y. Galectin-3 augments K-Ras activation and triggers a Ras signal that attenuates ERK but not phosphoinositide 3-kinase activity. J Biol Chem (2004) 279:34922-30. doi:10.1074/ jbc.M312697200

92. Shalom-Feuerstein R, Cooks T, Raz A, Kloog Y. Galectin-3 regulates a molecular switch from N-Ras to K-Ras usage in human breast carcinoma cells. Cancer Res (2005) 65:7292-300. doi:10.1158/0008-5472.CAN-05-0775

93. Shalom-Feuerstein R, Plowman SJ, Rotblat B, Ariotti N, Tian T, Hancock $\mathrm{JF}$, et al. K-Ras nanoclustering is subverted by overexpression of the scaffold protein galectin-3. Cancer Res (2008) 68:6608-16. doi:10.1158/0008-5472. CAN-08-1117

94. Levy R, Grafi-Cohen M, Kraiem Z, Kloog Y. Galectin-3 promotes chronic activation of K-Ras and differentiation block in malignant thyroid carcinomas. Mol Cancer Ther (2010) 9:2208-19. doi:10.1158/1535-7163.MCT-10-0262

95. Song S, Ji B, Ramachandran V, Wang H, Hafley M, Logsdon C, et al. Overexpressed galectin-3 in pancreatic cancer induces cell proliferation and invasion by binding Ras and activating Ras signaling. PLoS One (2012) 7:e42699. doi:10.1371/journal.pone.0042699

96. Saegusa J, Hsu DK, Liu W, Kuwabara I, Kuwabara Y, Yu L, et al. Galectin-3 protects keratinocytes from UVB-induced apoptosis by enhancing AKT activation and suppressing ERK activation. J Invest Dermatol (2008) 128:2403-11. doi:10.1038/jid.2008.119

97. Wu KL, Huang EY, Jhu EW, Huang YH, Su WH, Chuang PC, et al. Overexpression of galectin-3 enhances migration of colon cancer cells related to activation of the K-Ras-Raf-Erk1/2 pathway. J Gastroenterol (2013) 48:350-9. doi:10.1007/s00535-012-0663-3

98. Gao X, Balan V, Tai G, Raz A. Galectin-3 induces cell migration via a calcium-sensitive MAPK/ERK1/2 pathway. Oncotarget (2014) 5:2077-84. doi:10.18632/oncotarget.1786

99. Mori Y, Akita K, Yashiro M, Sawada T, Hirakawa K, Murata T, et al. Binding of galectin-3, a $\beta$-galactoside-binding lectin, to MUC1 protein enhances phosphorylation of extracellular signal-regulated kinase $1 / 2$ (ERK1/2) and Akt, promoting tumor cell malignancy. J Biol Chem (2015) 290:26125-40. doi:10.1074/jbc.M115.651489

100. Melo FH, Butera D, Junqueira MES, Hsu DK, Da Silva AM, Liu FT, et al. The promigratory activity of the matricellular protein galectin-3 depends on the activation of PI-3 kinase. PLoS One (2011) 6:e29313. doi:10.1371/journal. pone. 0029313

101. Borges BE, Teixeira VR, Appel MH, Steclan CA, Rigo F, Filipak Neto F, et al. De novo galectin-3 expression influences the response of melanoma cells to isatin-Schiff base copper (II) complex-induced oxidative stimulus. Chem Biol Interact (2013) 206:37-46. doi:10.1016/j.cbi.2013.08.005
102. Dange MC, Agarwal AK, Kalraiya RD. Extracellular galectin-3 induces MMP9 expression by activating $\mathrm{p} 38$ MAPK pathway via lysosome-associated membrane protein-1 (LAMP1). Mol Cell Biochem (2015) 404:79-86. doi:10.1007/s11010-015-2367-5

103. Gilmore TD. Introduction to NF-kappaB: players, pathways, perspectives. Oncogene (2006) 25:6680-4. doi:10.1038/sj.onc.1209954

104. Dumic J, Lauc G, Flögel M. Expression of galectin-3 in cells exposed to stress-roles of jun and NF-kappaB. Cell Physiol Biochem (2000) 10:149-58. doi: $10.1159 / 000016345$

105. Liu L, Sakai T, Sano N, Fukui K. Nucling mediates apoptosis by inhibiting expression of galectin-3 through interference with nuclear factor kappaB signalling. Biochem J (2004) 380:31-41. doi:10.1042/bj20031300

106. Zeng Y, Danielson KG, Albert TJ, Shapiro IM, Risbud MV. HIF-1 alpha is a regulator of galectin-3 expression in the intervertebral disc. J Bone Miner Res (2007) 22:1851-61. doi:10.1359/jbmr.070620

107. Neder L, Marie SK, Carlotti CG, Gabbai AA, Rosemberg S, Malheiros SM, et al. Galectin-3 as an immunohistochemical tool to distinguish pilocytic astrocytomas from diffuse astrocytomas, and glioblastomas from anaplastic oligodendrogliomas. Brain Pathol (2004) 14:399-405. doi:10.111 1/j.1750-3639.2004.tb00083.x

108. Rêgo MJ, Vieira de Mello GS, da Silva Santos CA, Chammas R, Beltrão EI. Implications on glycobiological aspects of tumor hypoxia in breast ductal carcinoma in situ. Med Mol Morphol (2013) 46:92-6. doi:10.1007/ s00795-013-0013-4

109. Ikemori RY, Machado CM, Furuzawa KM, Nonogaki S, Osinaga E, Umezawa $\mathrm{K}$, et al. Galectin-3 up-regulation in hypoxic and nutrient deprived microenvironments promotes cell survival. PLoS One (2014) 9:e111592. doi:10.1371/ journal.pone. 0111592

110. Serizawa N, Tian J, Fukada H, Baghy K, Scott F, Chen X, et al. Galectin 3 regulates HCC cell invasion by RhoA and MLCK activation. Lab Invest (2015) 95:1145-56. doi:10.1038/labinvest.2015.77

111. Allenspach EJ, Maillard I, Aster JC, Pear WS. Notch signaling in cancer. Cancer Biol Ther (2002) 1:466-76. doi:10.4161/cbt.1.5.159

112. Hsu YL, Wu CY, Hung JY, Lin YS, Huang MS, Kuo PL. Galectin-1 promotes lung cancer tumor metastasis by potentiating integrin $\alpha 6 \beta 4$ and Notch1/ Jagged2 signaling pathway. Carcinogenesis (2013) 34:1370-81. doi:10.1093/ carcin/bgt040

113. Fermino ML, Dias FC, Lopes CD, Souza MA, Cruz Â, Liu FT, et al. Galectin-3 negatively regulates the frequency and function of $\mathrm{CD} 4(+) \mathrm{CD} 25(+)$ Foxp3(+) regulatory $\mathrm{T}$ cells and influences the course of Leishmania major infection. Eur J Immunol (2013) 43:1806-17. doi:10.1002/eji.201343381

114. Nakajima K, Kho DH, Yanagawa T, Harazono Y, Gao X, Hogan V, et al. Galectin-3 inhibits osteoblast differentiation through notch signaling. Neoplasia (2014) 16:939-49. doi:10.1016/j.neo.2014.09.005

115. Shetty P, Bargale A, Patil BR, Mohan R, Dinesh US, Vishwanatha JK, et al. Cell surface interaction of annexin A2 and galectin- 3 modulates epidermal growth factor receptor signaling in Her-2 negative breast cancer cells. Mol Cell Biochem (2015) 411:221-33. doi:10.1007/s11010-015-2584-y

116. Sun W, Li L, Yang Q, Shan W, Zhang Z, Huang Y. G3-C12 peptide reverses galectin-3 from foe to friend for active targeting cancer treatment. Mol Pharm (2015) 12:4124-36. doi:10.1021/acs.molpharmaceut.5b00568

117. Park GB, Kim DJ, Kim YS, Lee HK, Kim CW, Hur DY. Silencing of galectin-3 represses osteosarcoma cell migration and invasion through inhibition of FAK/Src/Lyn activation and $\beta$-catenin expression and increases susceptibility to chemotherapeutic agents. Int J Oncol (2015) 46:185-94. doi:10.3892/ ijo.2014.2721

118. Kobayashi T, Shimura T, Yajima T, Kubo N, Araki K, Tsutsumi S, et al. Transient gene silencing of galectin-3 suppresses pancreatic cancer cell migration and invasion through degradation of $\beta$-catenin. Int $J$ Cancer (2011) 129:2775-86. doi:10.1002/ijc.25946

119. Zheng D, Hu Z, He F, Gao C, Xu L, Zou H, et al. Downregulation of galectin-3 causes a decrease in UPAR levels and inhibits the proliferation, migration and invasion of hepatocellular carcinoma cells. Oncol Rep (2014) 32:411-8. doi:10.3892/or.2014.3170

120. Wang YG, Kim SJ, Baek JH, Lee HW, Jeong SY, Chun KH. Galectin-3 increases the motility of mouse melanoma cells by regulating matrix metalloproteinase-1 expression. Exp Mol Med (2012) 44:387-93. doi:10.3858/ emm.2012.44.6.044 
121. Kim SJ, Shin JY, Lee KD, Bae YK, Choi IJ, Park SH, et al. Galectin-3 facilitates cell motility in gastric cancer by up-regulating protease-activated receptor-1 (PAR-1) and matrix metalloproteinase-1 (MMP-1). PLoS One (2011) 6:e25103. doi:10.1371/journal.pone.0025103

122. Meng F, Joshi B, Nabi IR. Galectin-3 overrides PTRF/Cavin-1 reduction of PC3 prostate cancer cell migration. PLoS One (2015) 10:e0126056. doi:10.1371/journal.pone.0126056

123. Boscher C, Nabi IR. Galectin-3- and phospho-caveolin-1-dependent outside-in integrin signaling mediates the EGF motogenic response in mammary cancer cells. Mol Biol Cell (2013) 24:2134-45. doi:10.1091/mbc. E13-02-0095

124. Shankar J, Wiseman SM, Meng F, Kasaian K, Strugnell S, Mofid A, et al. Coordinated expression of galectin-3 and caveolin-1 in thyroid cancer. J Pathol (2012) 228:56-66. doi:10.1002/path.4041

125. Lakshminarayan R, Wunder C, Becken U, Howes MT, Benzing C, Arumugam $\mathrm{S}$, et al. Galectin-3 drives glycosphingolipid-dependent biogenesis of clathrin-independent carriers. Nat Cell Biol (2014) 16:595-606. doi:10.1038/ ncb2970

126. Liu W, Hsu DK, Chen HY, Yang RY, Carraway KL, Isseroff RR, et al. Galectin-3 regulates intracellular trafficking of EGFR through Alix and promotes keratinocyte migration. J Invest Dermatol (2012) 132:2828-37. doi:10.1038/jid.2012.211

127. Cui G, Cui M, Li Y, Liang Y, Li W, Guo H, et al. Galectin-3 knockdown increases gefitinib sensitivity to the inhibition of EGFR endocytosis in gefitinib-insensitive esophageal squamous cancer cells. Med Oncol (2015) 32:124. doi:10.1007/s12032-015-0570-6

128. Mazurek N, Byrd JC, Sun Y, Hafley M, Ramirez K, Burks J, et al. Cell-surface galectin-3 confers resistance to TRAIL by impeding trafficking of death receptors in metastatic colon adenocarcinoma cells. Cell Death Differ (2012) 19:523-33. doi:10.1038/cdd.2011.123

129. Bergers G, Benjamin LE. Tumorigenesis and the angiogenic switch. Nat Rev Cancer (2003) 3:401-10. doi:10.1038/nrc1093

130. Dufraine J, Funahashi Y, Kitajewski J. Notch signaling regulates tumor angiogenesis by diverse mechanisms. Oncogene (2008) 27:5132-7. doi:10.1038/ onc.2008.227

131. Hanahan D, Folkman J. Patterns and emerging mechanisms of the angiogenic switch during tumorigenesis. Cell (1996) 86:353-64. doi:10.1016/ S0092-8674(00)80108-7

132. Bridges $\mathrm{E}, \mathrm{O}$ on $\mathrm{CE}$, Harris A. Notch regulation of tumor angiogenesis. Future Oncol (2011) 7:569-88. doi:10.2217/fon.11.20

133. Sakurai $\mathrm{T}$, Kudo M. Signaling pathways governing tumor angiogenesis. Oncology (2011) 81 (Suppl 1):24-9. doi:10.1159/000333256

134. Demetriou M, Granovsky M, Quaggin S, Dennis JW. Negative regulation of T-cell activation and autoimmunity by Mgat $5 \mathrm{~N}$-glycosylation. Nature (2001) 409:733-9. doi:10.1038/35055582

135. Lajoie P, Goetz JG, Dennis JW, Nabi IR. Lattices, rafts, and scaffolds: domain regulation of receptor signaling at the plasma membrane. J Cell Biol (2009) 185:381-5. doi:10.1083/jcb.200811059

136. Nabi IR, Shankar J, Dennis JW. The galectin lattice at a glance. J Cell Sci (2015) 128:2213-9. doi:10.1242/jcs.151159

137. Nangia-Makker P, Honjo Y, Sarvis R, Akahani S, Hogan V, Pienta KJ, et al. Galectin-3 induces endothelial cell morphogenesis and angiogenesis. Am J Pathol (2000) 156:899-909. doi:10.1016/S0002-9440(10)64959-0

138. Shekhar MP, Nangia-Makker P, Tait L, Miller F, Raz A. Alterations in galectin-3 expression and distribution correlate with breast cancer progression: functional analysis of galectin-3 in breast epithelial-endothelial interactions. Am J Pathol (2004) 165:1931-41. doi:10.1016/S0002-9440(10)63245-2

139. Machado CM, Andrade LN, Teixeira VR, Costa FF, Melo CM, Dos Santos SN, et al. Galectin-3 disruption impaired tumoral angiogenesis by reducing VEGF secretion from TGF 1 -induced macrophages. Cancer Med (2014) 3:201-14. doi:10.1002/cam4.173
140. D'Haene N, Sauvage S, Maris C, Adanja I, Le Mercier M, Decaestecker C, et al. VEGFR1 and VEGFR2 involvement in extracellular galectin-1- and galectin-3-induced angiogenesis. PLoS One (2013) 8:e67029. doi:10.1371/ journal.pone.0067029

141. Nangia-Makker P, Raz T, Tait L, Hogan V, Fridman R, Raz A. Galectin-3 cleavage: a novel surrogate marker for matrix metalloproteinase activity in growing breast cancers. Cancer Res (2007) 67:11760-8. doi:10.1158/00085472.CAN-07-3233

142. Nangia-Makker P, Wang Y, Raz T, Tait L, Balan V, Hogan V, et al. Cleavage of galectin- 3 by matrix metalloproteases induces angiogenesis in breast cancer. Int J Cancer (2010) 127:2530-41. doi:10.1002/ijc.25254

143. Nieminen J, Kuno A, Hirabayashi J, Sato S. Visualization of galectin-3 oligomerization on the surface of neutrophils and endothelial cells using fluorescence resonance energy transfer. J Biol Chem (2007) 282:1374-83. doi:10.1074/jbc.M604506200

144. Sano H, Hsu DK, Yu L, Apgar JR, Kuwabara I, Yamanaka T, et al. Human galectin-3 is a novel chemoattractant for monocytes and macrophages. J Immunol (2000) 165:2156-64. doi:10.4049/jimmunol.165.4.2156

145. Dragomir AC, Sun R, Choi H, Laskin JD, Laskin DL. Role of galectin-3 in classical and alternative macrophage activation in the liver following acetaminophen intoxication. J Immunol (2012) 189:5934-41. doi:10.4049/ jimmunol.1201851

146. Chen P, Bonaldo P. Role of macrophage polarization in tumor angiogenesis and vessel normalization: implications for new anticancer therapies. Int Rev Cell Mol Biol (2013) 301:1-35. doi:10.1016/B978-0-12-407704-1.00001-4

147. Jia W, Kidoya H, Yamakawa D, Naito H, Takakura N. Galectin-3 accelerates M2 macrophage infiltration and angiogenesis in tumors. Am J Pathol (2013) 182:1821-31. doi:10.1016/j.ajpath.2013.01.017

148. Wiseman DM, Polverini PJ, Kamp DW, Leibovich SJ. Transforming growth factor-beta (TGF beta) is chemotactic for human monocytes and induces their expression of angiogenic activity. Biochem Biophys Res Commun (1988) 157:793-800. doi:10.1016/S0006-291X(88)80319-X

149. Derynck R, Akhurst RJ, Balmain A. TGF-beta signaling in tumor suppression and cancer progression. Nat Genet (2001) 29:117-29. doi:10.1038/ ng1001-117

150. Etulain J, Negrotto S, Tribulatti MV, Croci DO, Carabelli J, Campetella O, et al. Control of angiogenesis by galectins involves the release of plateletderived proangiogenic factors. PLoS One (2014) 9:e96402. doi:10.1371/ journal.pone.0096402

151. Maniotis AJ, Folberg R, Hess A, Seftor EA, Gardner LM, Peer J, et al. Vascular channel formation by human melanoma cells in vivo and in vitro: vasculogenic mimicry. Am J Pathol (1999) 155:739-52. doi:10.1016/ S0002-9440(10)65173-5

152. Hendrix MJ, Seftor EA, Seftor RE, Chao JT, Chien DS, Chu YW. Tumor cell vascular mimicry: novel targeting opportunity in melanoma. Pharmacol Ther (2016) 159:83-92. doi:10.1016/j.pharmthera.2016.01.006

153. Mourad-Zeidan AA, Melnikova VO, Wang H, Raz A, Bar-Eli M. Expression profiling of galectin-3-depleted melanoma cells reveals its major role in melanoma cell plasticity and vasculogenic mimicry. Am J Pathol (2008) 173:1839-52. doi:10.2353/ajpath.2008.080380

Conflict of Interest Statement: The authors declare that the research was conducted in the absence of any commercial or financial relationships that could be construed as a potential conflict of interest.

Copyright () 2016 Cardoso, Andrade, Bustos and Chammas. This is an open-access article distributed under the terms of the Creative Commons Attribution License (CC $B Y)$. The use, distribution or reproduction in other forums is permitted, provided the original author(s) or licensor are credited and that the original publication in this journal is cited, in accordance with accepted academic practice. No use, distribution or reproduction is permitted which does not comply with these terms. 